\title{
How to breathe a new life into the global mortgage market? - An alternative solution
}

\author{
Levente Kovacs \\ Institute of Finance and Accounting, \\ University of Miskolc, \\ Hungary \\ kovacs.levente@,bankszovetseg.bu \\ ORCID 0000-0002-6691-4505
}

\author{
Szabolcs Pasztor \\ Department of Economics and International Economics, \\ University of Public Service, \\ Hungary \\ pasztor.szabolcs@,uni-nke.bu \\ ORCID 0000-0001-8606-8142
}

Abstract. The growing population of the world, the rising standards of living in most of the countries coupled with the COVID-19 related inflation fears has called our attention to the issue of housing. The aim of the paper is to give a brief introduction to the anomalies of the global mortgage markets. After having studied different continents and countries, the most pressing problems are presented, and the study confirms the fact that in general the initial monthly obligations place a huge financial burden on households. This fact limits the room for manoeuvre of the young families when buying a property. With the concept of adjustable net present value of the repayments, a new mortgage market formula is introduced. In general the solution may provide more flexible monthly repayments in present value terms for the borrowers. The new approach could be an alternative to renting properties, it may help young families achieve home ownership and at the same time it may mitigate the problems of the currently rather unhealthy global mortgage market tendencies.

Keywords: global residential mortgage markets, new formula, adjustable net present value

JEL Classification: E43, G21, O18 


\section{INTRODUCTION}

The size of residential mortgages market of the world was 31,000 billion USD in 2018 (MRO, 2020). In these markets the interactions of the lenders and borrowers shape the most important characteristics and rules. Among the participants we find an ever increasing number of households and for many of them only the residential mortgages offer a possible solution for becoming homeowners. On the surface, this market is sizeable, effective and a helping hand for millions of people. Homeownership has been becoming an ever important issue in most parts of the world either because of a steady increase in the population or because of a constant need for new housing. Also the COVID-19 related inflation fears make those financial assets more lucrative with which inflation can be avoided.

However the aim of the paper is to challenge the effectiveness and sustainability of the residential mortgages markets which is to help the new homeowners. The study claims that in its current form the mortgage loans do not give a real boost for homeownership but pose a massive headache and financial bottleneck for the majority of the young families. The paper has a clear purpose of finding a better solution (formula) for the classical methodology of calculating the monthly repayments.

The study is structured as follows. The first section tries to shed more light on the various mortgage markets (Latin America, Africa, Asia, USA, and Europe) and the immense challenges are also presented. In the second part, the characteristics of the classical mortgage loans are discussed and it is argued that there is a fundamental problem with the current formula(s) we use. Namely, at the initial period the borrowers are overburdened by the monthly instalments while towards the end of the period their monthly obligations represent only a fraction of the income of the households. Consequently, the current characteristics of the mortgage hinder many families from becoming homeowners. Section three describes the current formula of mortgages and calculating the monthly repayments and section three with the help of mathematical and financial deduction develops a new formula for mortgages where the present value of the monthly repayments are held constant. Also, the cases of choosing the increasing/decreasing net present values (NPV) are presented. In this way the solution presented in the paper is generalized. The final section discusses the social and political implications of the proposed new formula and argues that with the new present value approach a new boost could be given to the residential mortgage markets of the world.

\section{A BRIEF INTRODUCTION INTO THE GLOBAL MORTGAGE MARKETS}

The residential mortgage markets are underdeveloped in Latin America but there are a couple of countries (for example Chile and Brazil) where there are promising signs. The number of mortgage loans increased by 14 percent after inflation adjustment between 2003 and 2012 coupled with increasing property prices and flourishing construction sector. However we have to take into consideration that, with the exception of Chile, the size of the mortgage market in Latin America is not comparable with that of the emerging Asian countries or the USA. Behind this pattern we have to point to the macroeconomic instability of the region (credit crises, weak institutions) (Cottarelli et al., 2005). The Latin American credit/GDP indicator is quite high but the mortgage market reaches only 7 percent of the GDP (IMF, 2012). The residential mortgages represent only 20 percent of loans provided by the commercial banks. Furthermore the recent increase in the number of residential mortgages is attributed to non-classical features of the mortgage models (for example the Mihna casa, minha vida program in Brazil). Taking into consideration the relatively young population and the visible increase of the population, it is quite clear that the mortgage markets of the Latin American countries in their current forms are far from solving the shortage of houses and apart from the government programs there is a strong need for private investments and better mortgage constructions. 
We can hardly find any countries in Sub-Saharan Africa where the residential mortgage per GDP ratio exceeds 5 percent (only South Africa and Namibia are exceptions) (CAFH, 2016). So the mortgage markets are largely underdeveloped in the region but North Africa is in a bit better situation. It is a widely-known fact that the room for manoeuvre could be greater in the African continent but the majority of the households simply does not have access to the residential mortgage loans (Walley, 2010). Furthermore, we have to point to the fact that the African continent faces a demographic transformation (in the next 40 years there will be more than 2.4 billion people living there) and the demand for new homes would surge. Also we have to highlight that there will be more than 300 million people living in urban areas by 2030 (Pasztor, 2017). Currently it seems that the African governments are not capable of handling the increasing demand and easing the problems of the shortage of homes. Without the involvement of the private sector and the commercial banks it would be quite impossible to breathe a new life in to the residential mortgage markets in the region.

When it comes to Asia, the first feature to be highlighted is the huge heterogeneity of the residential mortgage markets (Kobayasi, 2016) as the residential mortgage per GDP ratio is 9 percent in India, 20 percent in Thailand, 41 percent in Japan, 45 percent in Hong Kong and 56 percent in Singapore (HOFINET, 2017). Currently the per capita GDP is four times bigger and it was in 1990 and as a consequence, among others, the mortgage market has been changing remarkably. Despite the break-neck economic growth the residential mortgage markets are still in the state of development so opportunities and challenges abound (Kobayasi, 2012). The most common type of mortgages in Asia is the adjustable rate mortgage (ARM), the fixed rate mortgage (FRM) also the combination of the two is popular. The loan to value (LTV) ratio is around 70 and 80 percent and the duration is around 20 and 30 years. Apart from the dynamism and the similar features of the residential mortgage markets in Asia we have to point to the fact that these markets show sluggish growth in a number of countries and the overall performance of the market cannot be compared to the markets of the developed world. Also the value of the residential mortgage loans to GDP is still low in many cases. In addition, the challenges are on the doorstep as in the rapidly growing India the number of middle class citizens and the rate of urbanisation has been increasing. According to Lindfield (2016) for example by 203055 percent of the population of the world would live in cities and there will be much more Indian urban dwellers. Cities like Bangkok, Tokyo or Manila give a huge share of the national GDP still there is not enough supply of homes and it is quite difficult to buy a property for millions of people. Yoshino and Helble (2016) argues for example that there is a need for new a solution and among others they point to the reduction of the interest of the residential mortgage loans.

As far as the USA is concerned we have to point to the fact that renting a flat was important before and after the 2008 financial and economic crisis as well (Boeing \& Wadell, 2016). This is feature is the consequence of the larger labour mobility of the USA in comparison with European Union (EU) countries (Barslund \& Busse, 2016). Owing to the high property prices, home ownership is an option for mainly the older generations and for those who live in rural areas. For the real homeowners, mortgages are valid options when the monthly instalment is an alternative to the rent. It is usually the case when the key interest rate is low. The financial and economic crisis of 2008 was triggered by the towering interest rate which resulted in continuously increasing monthly repayments and after a crucial moment they became higher than the rent. Also we saw a dramatic decrease of the price of those homes which had been purchased with the help residential mortgages. After some years, it became quite clear that the subprime crisis of the USA was triggered by the dysfunctional operation of the financial and mortgage markets (Gerlach, 2012; Kiraly, 2016). The success of the subprime mortgages was the result of the weakening of the credit standards in times of the low interest rate environment. Also the lenders became more open towards the riskier layers of the society and they started offering such mortgages which were available for the less credit-worthy borrowers as well (Demyanyk \& Hemert, 2011). The bubble of the mortgage market burst and after 2008 it turned out 
that basically the residential mortgages are not completely faulty but in case of unfortunate circumstances they can become toxic.

In the former socialist countries of Europe, the establishment of the mortgage markets was part of their financial development (Roy, 2008; Trojanek, 2009; Kostikov et al., 2019) but before the political changes, these markets were largely inefficient and underdeveloped. In the new EU member countries the credit/GDP ratio increased from 17 percent in 2000 to 55 percent in 2007. The total value of mortgages of the households did not reach 5 percent of the GDP in 2000 but by 2007 it exceeded 25 percent of the GDP. It is crucial to mention that until in the old EU member states the residential mortgages were denominated in the local currencies, the new EU member countries became indebted in foreign currencies (in EUR, CHF mainly). The ratio of foreign and domestic currency denominated mortgages was very heterogeneous as it was less than 1 percent in the Czech Republic and more than 90 percent in Romania. In Hungary most of the residential mortgage loans were denominated in CHF which as it turned out later proved to be lethal for the Hungarian households. Also there was a large percentage of ARMs in Hungary, Slovakia and Slovenia with rates of 80 percent.

In the old member states of the EU the value of residential mortgages was 27 percent of the GDP in 1999 and it increased to 42 percent by 2007. This rise was attributed to the lower interest rates and the more intense competition in the mortgage markets. The average value of the residential mortgages surged which was helped by the increase in their duration. In addition, new residential mortgages were phased in, which enabled the citizens to borrow more intensively (with higher mortgage/capital rates). In 2007 the per capita indebtedness indicator reached a record level in 2007 (Bouyon, 2017). After 2008, the regulation of the financial systems changed and the mortgage lending management became more cautious. We have seen a large decline in the value of mortgages in some old EU member countries especially in those countries (Spain, Portugal, and Ireland) where the level of indebtedness was already high. By 2016 the mortgage markets became double-faced. In some countries they still offer ARMs while in other countries the FRMs are used. However the FRMs has started dominating, the markets. We have to take into consideration that with the improvements in the labour markets and owing to the economic growth and lower interest rates, the aggregated gross borrowing rates have been following that growth tendency which started in 2012 and they almost reach the 2007 level. They try to prevent the markets from overheating and they phased in macroprudential regulations which may overregulate the mortgage sector. The LTV rules are stricter for example. As the regulators claim; there is a need for preventing the borrowers from becoming indebted and in case of Sweden they phased in especially strict loan to income (LTI) ratios (SBA, 2017). Currently, in the old EU member states the overregulation hinders the families from becoming homeowners.

After giving a general picture on the global mortgage markets, we can conclude that there are a number of difficulties, bottlenecks to overcome. In the following sections the payment parameters of the mortgages will be analysed and with the help of a financial and mathematical deduction a new residential mortgage construction will be introduced. The aim is to offer a new and practical solution for the problems of the mortgages markets and home ownership.

\section{METHODOLOGY - CLASSIC ANNUITY LOANS VS LOANS WITH ADJUSTABLE PRESENT VALUES}

When studying the relevant literature on annuity loans, it becomes clear that a large number of papers deal with the optimal decision of the mortgage terms, monthly obligations but those papers rarely touches the basic formula used for calculating the regular financial burden on the households. The paper of Etter (1992) is a good example. According to him, mortgage loan calculations are based on present value concepts and his paper gives detailed instruction on how to calculate the payment, the interest, the principal, and the 
balance with the classical approach. Green \& Wachter (2005) studied the American mortgage market in historical and international context. They claim that there were no alternatives to the constant payment formula, and during the decades home mortgages increased quite rapidly for the American households. Much earlier Stansell \& Millar (1976) concluded that a variable rate mortgage payment remarkably increased relative to the net income during a high inflation period. Also they point to the fact that the variable payment does not place bigger financial burden on the households. Fuster \& Willen (2017) focused on the size of the monthly instalment and the mortgage default and they highlighted that very little is known about the importance of mortgage payment size for default. Their paper studied the hybrid adjustable-rate mortgages and concluded that the payment size has an economically large effect on repayment behaviour. They claim that there is a strong link between the default behaviour and the payment size but they do not offer an alternative to the well-known formula for calculation. Trojanek (2009) concluded that there was a remarkable growth in the Polish mortgage market and the dynamics of the sector was much higher than before. These conclusions are made without an analysis of the sustainability of the mortgage market; namely the paper focuses on the on the numerical growth of household mortgages only. The paper of Baek \& Reem \& Bilbeisi (2013) is quite recent and they devote a whole study to the issue of approximate rules to calculate monthly mortgage payments. They propose three approximate rules for the popular 15- and 30-year mortgage terms. Taking into consideration of the paper of Etter (1995) and presenting and defining the characteristics of mortgage loans and their impact, a few simplified hypotheses will be applied and a summary will be provided. We will provide a summary for these beforehand.

Determining the annuity-based, fixed-amount repayments on loans is of key importance. As a general rule it is to be deduced from annuity, reaching the following result (for consistency with later sections, $r$ is the reference interest rate, $m$ is the interest margin of the loan and let $R=r+m$, while $n$ is the number of repayments, often expressed in time units) (Kovacs \& Pasztor, 2019):

$$
\text { Monthly instalment }=\frac{\text { Amount borrowed }}{\frac{1}{\mathrm{R}}-\frac{1}{\mathrm{R}(1+\mathrm{R})^{\mathrm{n}}}}
$$

The paper offers an alternative to this formula with the help of the following method:

The amount borrowed is precisely equal to the present value of the monthly obligations $\left(X_{i}\right)$ discounted by $R=r+m$

$$
\text { Amount borrowed }=\sum_{\mathrm{i}=1}^{\mathrm{n}} \frac{\mathrm{x}_{\mathrm{i}}}{(1+\mathrm{R})^{\mathrm{i}}}
$$

For annuity repayment, the instalments are expected to be equal, so

$$
\mathrm{X}_{\mathrm{i}}=\mathrm{X}_{\mathrm{j}}=\mathrm{X}
$$

the form and sum formula of the general geometric sequence:

$$
\mathrm{S}_{\mathrm{n}}=\mathrm{a}_{1} \sum_{\mathrm{i}=1}^{\mathrm{n}} \mathrm{q}^{\mathrm{i}-1}=\mathrm{a}_{1} \cdot \frac{\mathrm{q}^{\mathrm{n}}-1}{\mathrm{q}-1}
$$

$X_{i}$ can be isolated from formula (2) because of its equivalence with (3) and furthermore, in this case, based on the following relationships: 


$$
\begin{gathered}
\mathrm{a}_{1}=\mathrm{q}=\frac{1}{1+\mathrm{R}} \\
\text { Amount borrowed }=\mathrm{X} \cdot \frac{1}{1+\mathrm{R}} \cdot \frac{\left(\frac{1}{1+\mathrm{R}}\right)^{\mathrm{n}}-1}{\frac{1}{1+\mathrm{R}}-1}
\end{gathered}
$$

of which $X$ is the following (left side) and then after having done the trivial simplifications (right side):

$$
X=\frac{\text { Amount borrowed } \cdot(1+\mathrm{R})\left(\frac{1}{1+\mathrm{R}}-1\right)}{\left(\frac{1}{1+\mathrm{R}}\right)^{\mathrm{n}}-1}=\frac{- \text { Amount borrowed } \cdot \mathrm{R}}{\left(\frac{1}{1+\mathrm{R}}\right)^{\mathrm{n}}-1}
$$

The equivalence of formulas (1) and (6) can be shown with the following rearrangement:

$$
\frac{1}{\frac{1}{\mathrm{R}}-\frac{1}{\mathrm{R}(1+\mathrm{R})^{\mathrm{n}}}}=\frac{-\mathrm{R}}{\left(\frac{1}{1+\mathrm{R}}\right)^{\mathrm{n}}-1}
$$

With both sides rearranged:

$$
\frac{1}{\frac{1}{\mathrm{R}} \cdot\left(1-\frac{1}{(1+\mathrm{R})^{\mathrm{n}}}\right)}=\frac{\mathrm{R}}{-\frac{1}{(1+\mathrm{R})^{\mathrm{n}}}+1}
$$

Dividing by the fraction $1 / R$, the left side is equivalent to multiplying by $R$ on the right as the reciprocal, and thus the two numerators and the two denominators are the same, so the two sides are equal. This confirms the equivalence of formulas (1) and (6). This proof was not gratuitous, as it prepares the ground for the later derivations and harmonization with the results.

The nominal and NPVs of classic annuity monthly obligations, discounted by $r$, are shown in Figure 1 in the context of a specific example. The interest rates here, and in what follows, are shown on a p.a. (per annum) basis, and the amount borrowed is denoted by $M$.

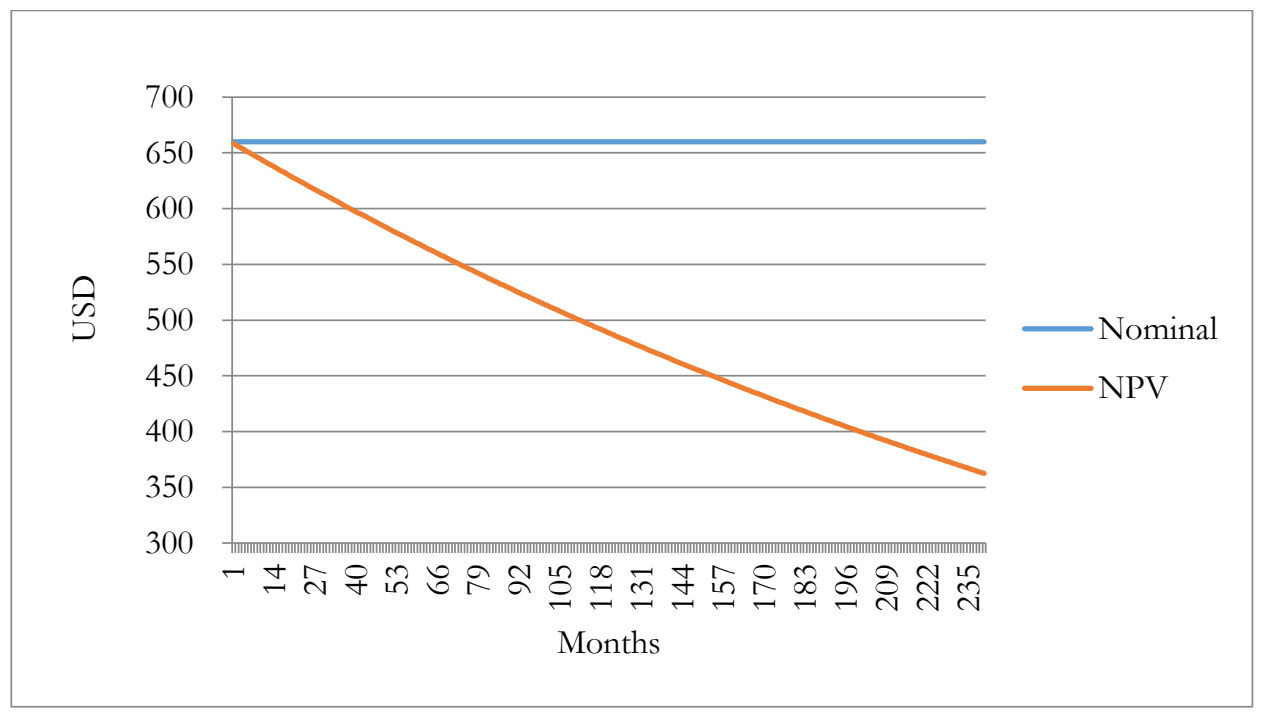

Figure 1. Nominal and present value of monthly obligations on a classic annuity loan

$$
(M=100,000 ; r=3 ; m=2 ; \mathrm{R}=r+m ; n=240)
$$

Source: The authors' calculations. 
As the figure shows, the "price” of having nominally equal repayments is that the initial repayment is relatively high; then as time passes, the monthly instalments continues to depreciate with inflation owing to the discount factor. If the income of property owners increases faster than what the assumed rate of growth for average income in the model (due to promotion or the recognition of considerable work experience, for example), and assuming that the cost of furnishing the home and the extra cost of having children also falls onto the time period directly after the home is bought, then the monthly obligation parameters of mortgage loans run counter to the consumer life cycle. The monthly instalments overburden young home buyers in the years following the home purchase, then later, in the second half of the term, they become negligible relative to the household's financial capacity. The situation is similar to investment loans, as the new investment causes the company's income-generating capacity to increase as time progresses, while the loan burden decreases contrary to this. In other words, here, the borrower is also overburdened during the initial period and under-burdened in the closing period. The impact of the interest rate change on the repayment is shown in Function (7), that is, the total derivative function of (1) with respect to $R$ :

$$
X^{\prime}(R)=- \text { Amount borrowed } \frac{\frac{-1}{\mathrm{R}^{2}}+\frac{1}{\mathrm{R}^{2}(1+\mathrm{R})^{\mathrm{n}}}+\frac{\mathrm{n}}{\mathrm{R}(1+\mathrm{R})^{\mathrm{n}+1}}}{\left(\frac{1}{\mathrm{R}}-\frac{1}{\mathrm{R}(1+\mathrm{R})^{\mathrm{n}}}\right)^{2}}
$$

The formula has been already introduced in one of our previous studies where constant NPVs were used and the current paper tries to introduce a more flexible approach with adjustable NPVs.

\section{EMPIRICAL RESULTS AND DISCUSSION}

As demonstrated in Table 1, the impact of the 1 percentage point increase in the interest rate on the sum of the instalments is exponential: 6-8 times the interest rate increase, at normal interest level! The derived function also demonstrates the same, fast increase.

There is an another issue to be observed in case of Figure 1 (which is convex): a change in the interest rate, remaining within the limits of market reality, influences the obligation to such an extent that if the interest rate environment lurches out of control it may actually cause social problems (Kovacs \& Pasztor, 2019).

Table 1

Interest rate dependency of annuity loan repayments

(Amount borrowed: 100,000 USD; terms: 240 months)

\begin{tabular}{|c|c|c|c|}
\hline $\begin{array}{c}\text { Interest }(\mathrm{R}) \\
\text { (percent) }\end{array}$ & Instalment (USD) & Nominal increase (USD) & Percentile increase \\
\hline 0 & 417 & - & - \\
\hline 1 & 460 & 43 & 9.40 \\
\hline 2 & 506 & 46 & 9.09 \\
\hline 3 & 555 & 49 & 8.78 \\
\hline 4 & 606 & 51 & 8.48 \\
\hline 5 & 660 & 54 & 8.18 \\
\hline 6 & 716 & 56 & 7.88 \\
\hline 7 & 775 & 59 & 7.59 \\
\hline 8 & 836 & 61 & 7.31 \\
\hline 9 & 900 & 63 & 7.03 \\
\hline 10 & 965 & 65 & 6.77 \\
\hline
\end{tabular}

Source: The authors' calculation. 


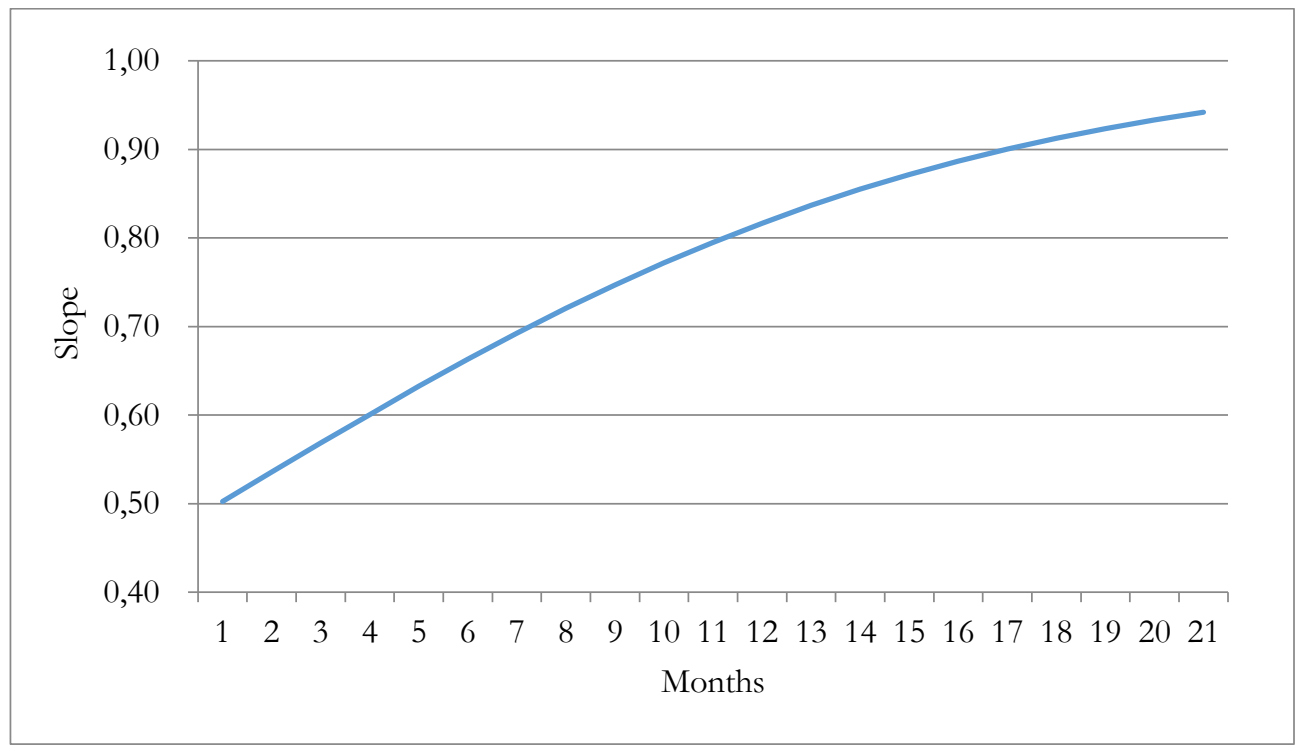

Figure 2. Slope of the monthly repayments of an annuity loan according to interest based on Formula (7) $(M=1, R=0-20, n=240)$

Source: The authors' calculations.

Due to the lender's risks, we should also look at the value and the present value of the outstanding principal debt during the term. Using the previous specific example, this is shown in Figure 3. Figure $3 a$ present the case when the NPV is constant. This is a highly likely situation but when thinking in general terms, changing NPVs are to be taken into consideration also. Figure $3 b$ presents the case when the monthly instalments increase while Figure $3 \mathrm{c}$ shows the changes in case of decreasing monthly obligations.

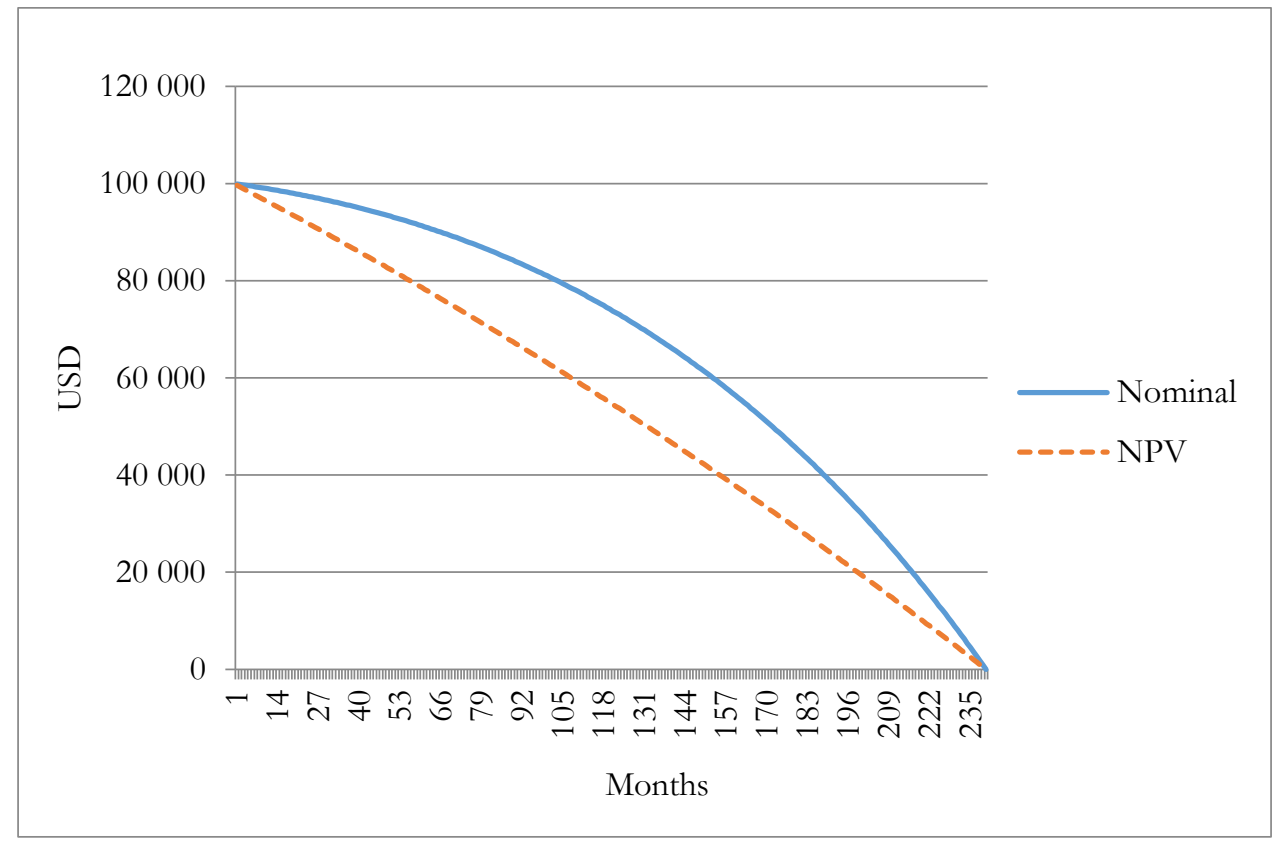

Figure 3a. Change in the nominal and present value of the outstanding principal of a classic annuity loan when the NPV is held constant $(M=100,000 ; r=3 ; m=2 ; \mathrm{R}=\mathrm{r}+\mathrm{m} ; \mathrm{v}=0 \% ; n=240)$

Source: The authors' calculation. 


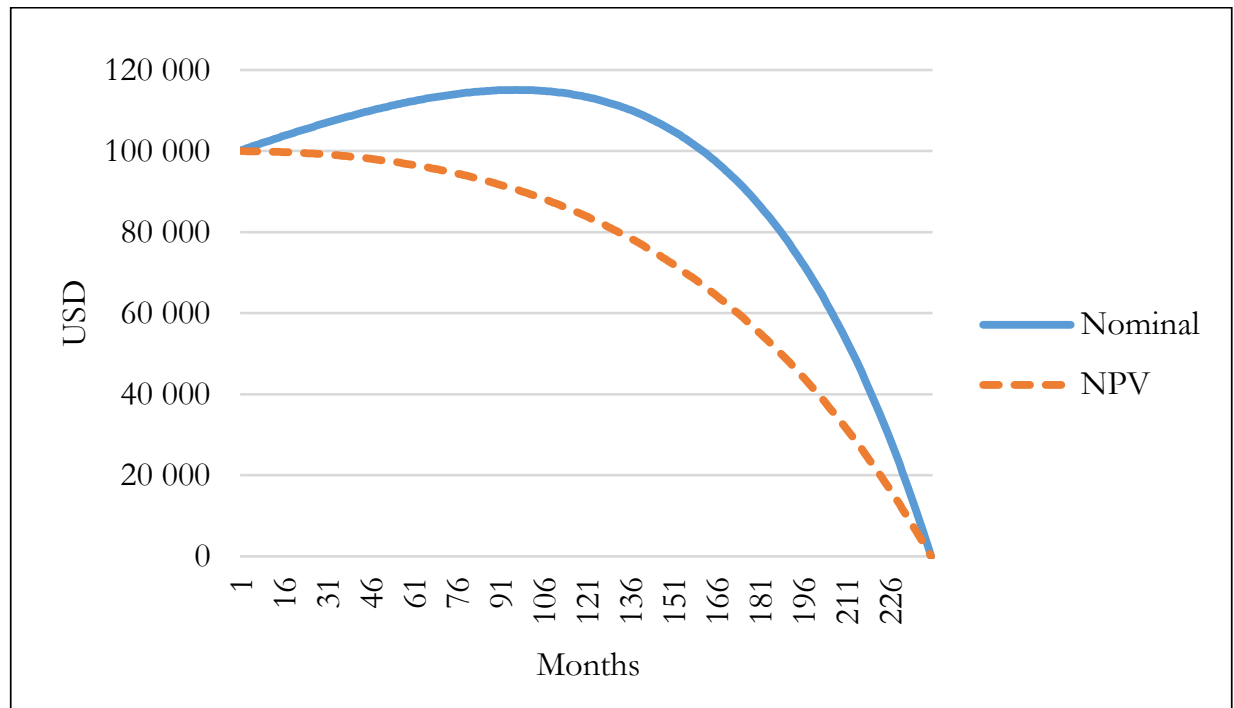

Figure $3 \mathrm{~b}$. Change in the nominal and present value of the outstanding principal of a classic annuity loan when the monthly instalments increase

$$
(M=100,000 ; r=3 ; m=2 ; \mathrm{R}=\mathrm{r}+\mathrm{m} ; \mathrm{v}=10 \% ; n=240)
$$

Source: The authors' calculation.

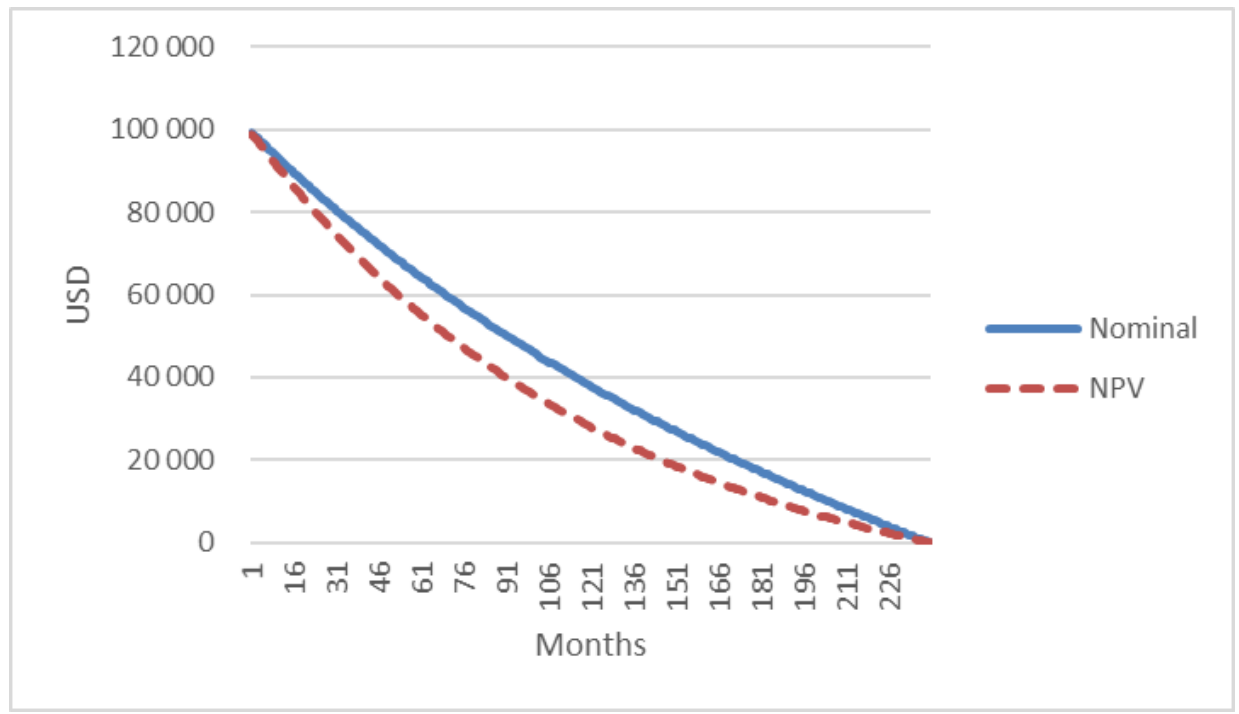

Figure 3c. Change in the nominal and present value of the outstanding principal of a classic annuity loan when the monthly instalments decrease

$$
(M=100,000 ; r=3 ; m=2 ; \mathrm{R}=\mathrm{r}+\mathrm{m} ; \mathrm{v}=-10 \% ; n=240)
$$

Source: The authors' calculation.

All of these scenarios (flexibility) are to be taken into consideration as the borrower may decide about whether he/she wants to keep the monthly obligations constant or increasing/decreasing. Promotions, ageing and a handful of other factors may influence this decision and it is up to the circumstances which one is the best borrower. By incorporating greater flexibility, the solution presented in the paper is generalized and the young families may decide about which NPV path of the monthly obligations they take. 
According to the model presented, the outstanding principal - due to the initial overburdening decreases rapidly but the rate of this decrease can be different when choosing alternative scenarios.

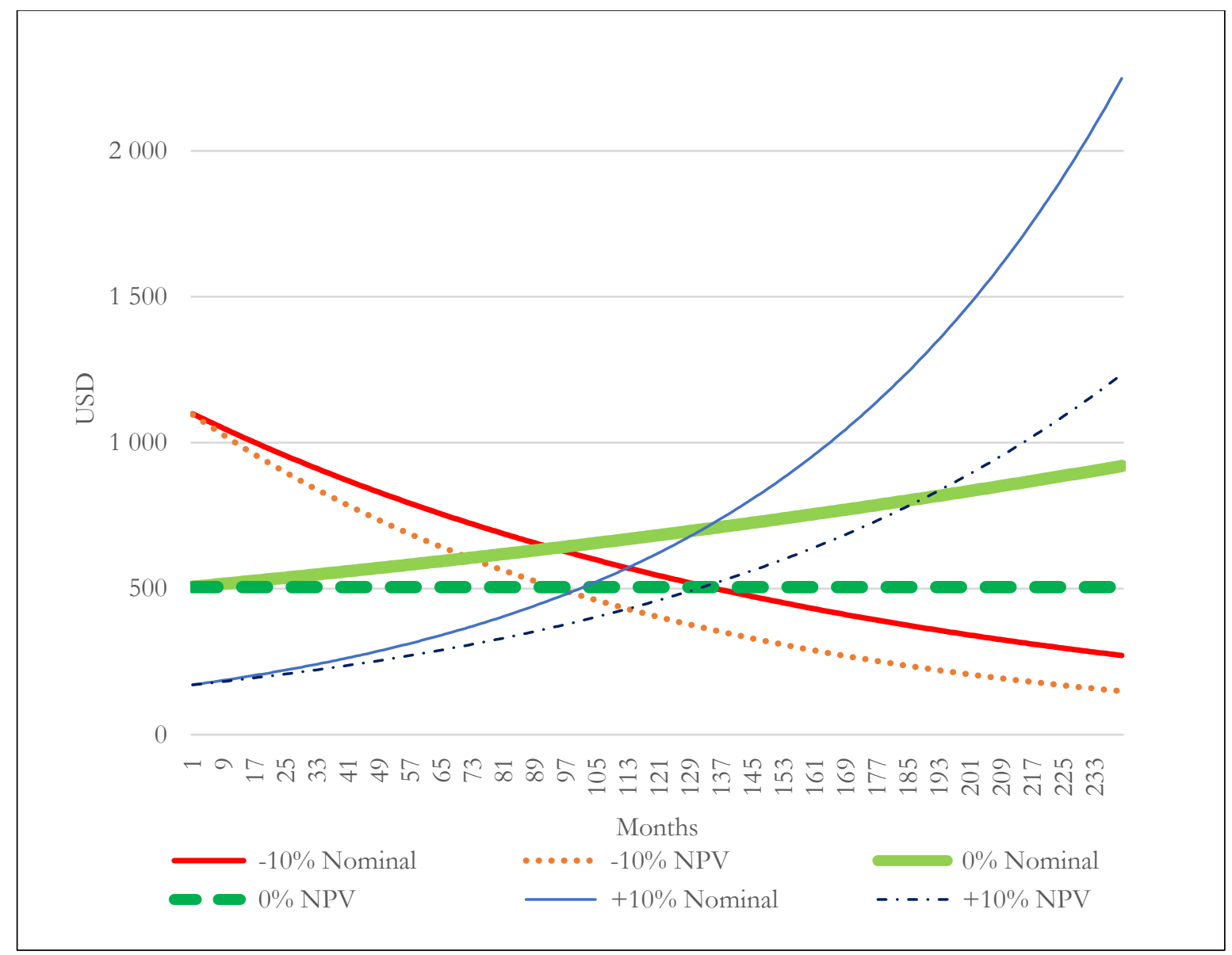

Figure 4. Alternative scenarios when using constant, decreasing, and increasing monthly obligations

$(M=100,000 ; r=3 ; m=2 ; \mathrm{R}=\mathrm{r}+\mathrm{m} ; \mathrm{v}=-10 \%$ or $0 \%$ or $10 \% ; n=240)$

Source: The authors' calculation.

To conclude, it is to be observed that for countries with a traditionally higher level of interest rates, a new repayment calculation method, one with more favourable for consumers, should be created. It would be more sustainable than the currently applied classic annuity loan repayment calculation i.e. which is nominally determined in the national currency. The goal is to keep the repayment affordable for the society throughout the entire term. An essential part of this is to significantly moderate the interest rate change impact for the new monthly obligation calculations. With the help of the new method the initial monthly payments are less than in comparison with the classical approach but as we approach the end of the maturity period the monthly repayments increase/decrease considerably. The new approach gives more financial freedom for the relatively young households and help them make calculated financial steps later.

From the perspective of the banking industry the paper argues that when a mortgage credit institution has a loan portfolio consisting of a large number of loans with a uniform distribution of time than based on the conditions applied in the paper ( $\mathrm{n}=240$ months, $\mathrm{r}=3 \%, \mathrm{~m}=2 \%, \mathrm{v}=0 \%$ ), there is a need for a $13.85 \%$ larger / more funding sources to maintain the current credit activity. However, the shape of the temporal 
function of the size of the funding sources portfolio is the same as the funding sources function of the classically repayment portfolio, either in the case of a constant or increasing/decreasing portfolio. This is easy to conclude since in both cases, due to the even distribution, the composition and size of the capital reserve existing at time $i$ of each loan element is exactly the same as its $i+1$. This is because a new credit enters the first place and one drops out of the last place, while each additional credit element advances one position, with exactly the same weight due to the assumed even distribution, and with the same value due to the stagnation. In the case of a steady increase/decrease, each new position receives exactly the new value corrected for the change. That is, each element changes by the same percent, so the total value also changes by exactly that percent. That is, the statement that the shape of the envelope of the multi-element, evenly distributed loan aggregation is independent of the repayment structure of each element can be considered as a lemma.

\section{CONCLUSION AND SUGGESTIONS}

The paper highlighted the fact that there is a need for reforming the mortgage loan markets and the housing needs of the world. It is quite obvious that there more sustainable mortgage loan facilities are needed and our classical approach is to be reconsidered. Among other issues at the moment, the issue of interest rate fluctuations (in its traditional sense, variable interest facilities) is not being addressed properly. The currently applied classic annuity mortgage loan facilities do not guarantee a sustainable and alternative solution to renting. Meanwhile the housing situation in several emerging and developing countries continue to deteriorate as their populations increase at a rapid rate and at the same time there is an ever increasing need for new homes. In the advanced countries COVID-19 related inflation fears also enter into the picture and make situation even more complex.

Based on the presented monthly instalment parameters, classic mortgage loans overburden young families in the initial period of the mortgages. Later when the monthly obligations depreciate with inflation towards their final period, their advantages become apparent. Basically this trend is contrary to the natural human cycle according to which employees are promoted and usually have much higher income than previously. Later and to a certain extent at the same time the expenses of their families decrease as their children grow up and become adults. Owing to the obsolete mortgage loans, instead of becoming homeowners, many are left with renting. This is their only choice for housing, especially if they are unable to put up a substantial down payment. After having detected the increasing number of challenges, the paper tried to define a new, previously unknown mortgage loan facility. The aim was to make the present value of the repayment constant (or flexible by letting the borrower decide) instead of the nominal instalment. Based on the new formula presented in the paper, the initial monthly instalments are generally lower and the borrower may decide about what track he/she wants to take in case of the NPV of the repayments.

The repayment formula defined for the present value of the optimal, constant repayment:

$$
\mathrm{X}_{\mathrm{i}}=\frac{\text {-Amount borrowed } \cdot \mathrm{m}(1+\mathrm{r})^{\mathrm{i}-1}}{\left(\frac{1+\mathrm{r}}{1+\mathrm{r}+\mathrm{m}}\right)^{\mathrm{n}}-1}
$$

The introduction of the new mortgage facility presented in the paper would have an extensive social impact, since it would, from a financial perspective, provide a real boost for home ownership and could be a real alternative to renting. 


\section{ACKNOWLEDGEMENT}

The research was financed by the Research Institute of Competitiveness and Economy at the University of Public Service, Budapest, Hungary.

\section{REFERENCES}

Baek, C., Reem, J., \& Bilbeisi, K. (2013). Approximate rules to calculate monthly morgage repayments. Journal of Business, Economics \& Finance, 2(1), 5-12.

Barslund, M., \& Busse, M. (2016). Labour Mobility in the EU. Addressing Challenges and Ensuring Fair Mobility. CEPS Special Report, No. 139. Retrieved 12 January https://www.ceps.eu/system/files/SR139\%20MB\%20and\%20MB\%20LabourMobility.pdf.

Boeing, G., \& Waddell, P. (2016). New Insights into Retail Housing Markets across the United States. Journal of Planning Education and Research, 37(4), 457-476, https://doi.org/10.1177/0739456x16664789.

Bouyon, S. (2017). Recent Trends and Development in European Mortgage Markets. ECRI Commentary, No. 21. Retrieved 12 May 2020, from https://www.ceps.eu/system/files/No\%2021\%20SB Trends\%20in \%20Mortgage $\% 20$ Markets.pdf.

Cottarelli, C., Ariccia, G. D., \& Vladkova-Hollar, I. (2005): Early birds, late risers, and sleeping beauties: Bank credit growth to the private sector in Central and Eastern Europe and in the Balkans. Journal of Banking and Finance, 29(1), 83-104. https://doi.org/10.1016/j.jbankfin.2004.06.017

Demyanyk, Y., \& Hemert, O. van (2011). Understanding the Subprime Mortgage Crisis. Review of Financial Studies, 24(6), 1848-1880, https://doi.org/10.1093/rfs/hhp033.

EconStats.TM (2018). Interest rates and other economic indicators. Retrieved 12 December 2019, from http://www.econstats.com/r/rlib aa6.htm

Etter, W. E. (1995). Calculation Mortgage Loans. Investment, Publication 923, A Reprint from the Real Estate Center Journal, https://assets.recenter.tamu.edu/documents/articles/923.pdf

Fuster, A., \& Willen, P. S. (2017). Payment Size, Negative Equity, and Mortgage Default. American Economic Journal: Economic Policy, 9(4), 167-191.

Gerlach, S. (2012, April). Housing Markets and Financial Stability. Speech presented at the National University of Ireland, Galway. Bank of Ireland, Dublin.

Green, R. K., \& Wachter, S. M. (2005). The American Mortgage in Historical and International Context. Journal of Economic Perspectives, 19(4), 93-114. https://doi.org/10.1257/089533005775196660

HOFINET (Housing Finance Information Network) (2017). East Asia and the Pacific. Retrieved 28 June 2020, from http:/ / www.hofinet.org/countries/region.aspx?regionID=2\&id =7

Király, J., \& Simonovits, A. (2015). Servicing mortgage loans in forints and in foreign currency: simple models. Economic Review, 52(1), 1-26.

Király, J. (2016). Az amerikai másodrendü jelzálogpiaci és a magyar devizabitel-válság összebasonlitó elemzése. In: Gál, R. I. - Király, J. (Eds.): Simonovits 70. Társadalom- és természettudományi írások Arkhimédésztől az időskori jövedelmekig. MTA KRTK Közgazdaság-tudományi Intézet, Budapest, pp. 329-350.

Kishor, N. K., \& Morley, J. (2015). What factors drive the price-rent ratio for the housing market? A modified presentvalue analysis. Journal of Economic Dynamics and Control, 58(1), 235-249, https://doi.org/10.1016/j.jedc.2015.06.006

Knoll, K., Schularick, M., \& Steger, T. (2017). No Price Like Home: Global House Prices, 1870-2012. American Economic Review, 107(2), 331-353. https://doi.org/10.1257/aer.20150501

Kobayashi, M. (2012). Asian mortgage markets. European mortgage federation, Retrieved 12 March 2020, from https://www.jhf.go.jp/ files/300120935.pdf.

Kobayashi, M. (2016). Housing market and bousing policies in Japan. ADBI Working Paper Series, No. 558. Asian Development Bank Institute, Retrieved 1 May 2019, from https://www.adb.org/sites/default/files/publication/181404/adbi-wp558.pdf. 
Kostikov, E., Jílková, P., \& Kot'láková Stránská, P. (2019). Quantified impact of market interest rates on commercial banks' business mix. Journal of International Studies, 12(2), 258-269. https://doi.org/10.14254/2071$\underline{8330.2019 / 12-2 / 16}$

Kovacs, L., Pásztor, Sz. (2019). Characteristic of Mortgage Loans and a New Solution. Federalism, 3(4), 161-180. https://doi.org/10.21686/10.21686/2073-1051-2019-4-161-180

Lindfield, M. (2016). Challenges for sustainable urban development in Asia. Asian Development Bank. Retrieved 22 April 2020, from https://k-learn.adb.org/system/files/materials/2016/10/201610-challengessustainable-urbandevelopment-asia.pdf.

MRO (Market Reports Online) (2020). Global residential industry guide. Retrieved 12 June 2020, from https://www.marketreportsonline.com/451719.html.

Philiponnet, N., \& Turrini, A. (2017). Assessing house price developments in the EU. European Commission, Discussion Paper, 048. Retrieved 23 September 2019, from https://ec.europa.eu/info/sites/info/files/dp048 en.pdf

Radnai, M. (2015). The boomerang effect of repricing household foreign-currency mortgage loans. Economic Review, 62(2), 113-138.

Roy, F. (2008): Mortgage markets in Central and Eastern Europe. A Review of Past Experiences and Future Perspectives. European Journal of Housing Policy, 8(2), 133-160. https://doi.org/10.1080/14616710802061953.

Stansell, S. R., \& Millar, J. A. (1976). An Empirical Study of Mortgage Payment to Income Ratios in a Variable Rate Mortgage Program. Journal of Finance, 31(2), 415-425.

Trojanek, M. (2009). The UK and Poland's mortgage markets: a comparative analysis. Journal of International Studies, 2(1), 26-39. https://doi.org/10.14254/2071-8330.2008/2-1/3

Walley, S. (2010, September). Housing finance in Africa. Are we post crisis yet?, Paper presented at the Annual Conference of the African Union for Housing Finance, Gaborone, Botswana.

Yoshino, N., \& Helble, M. (Eds.) (2016). The housing challenge in emerging Asia - options and solutions. Asian Development Bank Institute, Tokyo. Retrieved 23 May 2020, from https://www.adb.org/sites/default/files/publication/190060/adbi-housing-challenge-emerging-asiaoptionssolutions.pdf. 